\title{
ГРАМАТИЧНЕ ЗНАЧЕННЯ НЕРЕАЛЬНОГО УМОВНО-НАСЛІДКОВОГО ПЕРІОДУ
}

\begin{abstract}
Статтю присвячено визначенню граматичного значення різнооформлених нереальних умовно-наслідкових періодів (НУНП): з'ясовано природу умови та наслідки як понятійних категорій, щзо розглядаються філософією, логікою та лінгвістикою; проілюстровано різницю у тлумаченні ичих понять у межах зазначених наук; розглянуто універсальні риси цих категорій, які своєрідно виражені в мові та мовленні.

Умова і наслідок у філософії розглядаються як універсальні категорії, щзо відбивають об'єктивно наявні відношення між явищами реальної дійсності. Логіка трактує умову і наслідок як обов'язкові елементи єдиного складного судження, сформованого із простих суджень шляхом об' єднання їх знаком імплікації «якщо < ...> то <...>». У лінгвістиці умовно-наслідкові відношення належать до загальної системи смислових відношень як компоненти семантичної структури мовних одиниџь, вивчається специфіка їхнього вираження в мовленні.

Умова $і$ наслідок - понятійні категорії, щуо вивчаються у філософії, логіиі $i$ лінгвістииі, відображають об'єктивні зв'язки, відносини між подіями реальної дійсності. Оскільки зв'язок між умовою і наслідком об'єктивний, він пізнається свідомістю і відображається у складному судженні, мовним вираженням якого є умовно-наслідковий період.

Основними чинниками для виявлення їхнього граматичного значення в дослідженні прийнято вважати природу умовно-наслідкового відношення, представленого у складному умовно-наслідковому судженні й експлікованого в нереальному умовно-наслідковому періоді; різницю між реальною і гіпотетичною дійсністю.

Вираження умовно-наслідкового відношення між прочесами гіпотетичної дійсності є граматичним значенням не стільки форм дієслова, скільки синтаксичної конструкиії-нереального умовно-наслідкового періоду, щчо служить для мовного вираження складного умовно-наслідкового судження.
\end{abstract}

Ключові слова: нереальний умовно-наслідковий період, умовно-наслідкове відночення, умова, наслідок.

Tetiana KOVALCHUK, orcid.org/ 0000-0001-8342-5933

Candidate of Philological Sciences, Associate Professor at the Department of Foreign languages

Odesa Military Academy

(Odesa, Ukraine)16tanya20@gmail.com

\section{THE GRAMMATICAL MEANING OF THE UNREAL CONDITIONAL PERIOD}

The article is concerned with the determination of the grammatical meaning of various unreal conditionalconsequential periods (UCCP). The nature of the condition and consequence as conceptual categories considered by philosophy, logic, and linguistics was clarified in particular. Besides the difference in the interpretation of these concepts within the sciences mentioned above was illustrated. The universal features of these categories, which are expressed in language and speech peculiarly, were considered as well.

Condition and consequence are considered as universal categories in the philosophy that reflect the objectively existing relations between the phenomena of reality. Logic interprets condition and consequence as obligatory elements of a single complex judgment, formed from simple judgments by combining them with the sign of the implication "if $<\ldots>$ then <...>". Conditional-consequential relations belong to the general system of semantic relations in linguistics as components of the semantic structure of language units and the specific of their expression in speech is studied.

Condition and consequence - conceptual categories which are studied in philosophy, logic, and linguistics, reflect the objective connections, the relationships between the events of reality. Since the connection between the condition and the consequence is objective, it is known by consciousness and is reflected in a complex judgment, the linguistic expression of which is the conditional-consequential period.

The main factors for identifying their grammatical meaning in the research are considered to be the nature of the conditional-consequential relation, which is presented in a complex conditional-consequential judgment and explicated in the UCCP, as well as the difference between real and hypothetical reality. 
The expression of the conditional-consequential relation between the processes of hypothetical reality is a grammatical meaning, not so much of the verb forms as of the syntactic construction - UCCP, which serves for the linguistic expression of a complex conditional-consequential judgment.

Key words: unreal conditional-consequential period, conditional-consequential relation, condition, consequence.

Постановка проблеми. Діалектична єдність умови і наслідку в межах складного судження дає підставу терміну «нереально-умовний період», що використовується в лінгвістиці на позначення різноструктурних речень, що виражають нереальну умову, трактувати його як «нереальний умовно-наслідковий період» (далі - НУНП).

Аналіз досліджень. Дослідження НУНП як засобів вираження нереальної умови, вивчення форм і відповідних значень умовного способу дієслова, співвідношення цих форм із часовими параметрами, аналіз окремих моделей уживання форм умовного способу дієслова висвітлено у працях багатьох вітчизняних та закордонних дослідників (В. В. Гуревич, О. А. Зверева, О. А. Мартинюк, О. А. Палатова, С. Н. Рибакова, Т. К. Рушева, В. І. Сиволапова, Т. С. Фіногіна, І. Б. Хлєбнікова, В. С. Храковський, С. Гринбаум, С. Елсворт, О. Єсперсен, Р. Кверк, Дж. Керм, Дж. Ліч, Дж. Свартвік, М. Свон).

Мета статті - визначити граматичне значення різнооформлених НУНП, з'ясувати природу умови та наслідку як понятійних категорій, що розглядаються філософією, логікою та лінгвістикою; охарактеризувати тлумачення цих понять у межах зазначених наук.

Виклад основного матеріалу. Дослідження категорій умови і наслідку у філософії, логіці та лінгвістиці не може цілком збігатися через специфіку об'єктів і методів їх вивчення. У філософії об'єктом безпосереднього дослідження є відношення між реаліями, у логіці та лінгвістиці вивчаються прояви умовно-наслідкового відношення: через закони мислення в логіці-як судження, через закони мови в лінгвістиці - як речення. Умова i наслідок у філософії розглядаються як універсальні категорії, що відбивають об'єктивно наявні відношення між явищами реальної дійсності. Логіка умову і наслідок трактує як обов'язкові елементи єдиного складного судження, сформованого із простих суджень шляхом об'єднання їх

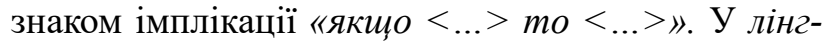
вістиці умовно-наслідкові відношення належать до загальної системи смислових відношень як компоненти семантичної структури мовних одиниць, вивчається специфіка їх вираження в мовленні. Логіка підкреслює специфічність умовнонаслідкового відношення: зв'язок встановлюється не між предметами та їхніми ознаками, а між подіями - тими ситуаціями, у які потрапляють предмети. Тобто умова й обумовлене (наслідок) належать до класу подій. Це підтверджується фактами їхнього лексико-граматичного вираження. У складному реченні умова й обумовлене представлені предикативними одиницями (умовна та наслідкова) - двома частинами єдиного цілого.

Просте речення, або предикативна одиниця, як вербальна репрезентація простого судження співвідноситься 3 елементарним процесом (подією) об'єктивної дійсності, що спостерігається і пізнається людиною. У НУНП кожна із предикативних одиниць у свідомості людини також співвідноситься 3 елементарним процесом, але дійсності мислимої, не/можливої, не/бажаної, гіпотетичної.

Складні речення, що виражають умовнонаслідкові зв'язки між предикативними одиницями, об'єднують взаємозалежні та такі, що взаємозумовлюють одна одну, предикативні одиниці. Взаємозалежність $є$ істотною характеристикою предикативного зв'язку, але умовно-наслідкова залежність є дещо іншою: предикація об'єднує слова в речення, тобто у прості судження, тоді як умовно (причинно)-наслідковий зв'язок об'єднує прості судження у складне. Взаємозумовлюючий характер зв'язку між умовою і наслідковою предикативною одиницею робить їх абсолютно обов'язковими як для структурної, так і насамперед для семантичної цілісності висловлювання; тому вони і не піддаються розподіленню на «головне» $\mathrm{i}$ «підрядне» речення.

Людина у своїй свідомості фіксує і своєрідно відображає як власний особистий досвід, так і досвід, накопичений людством у процесі еволюції. Цей досвід узагальнює знання, інформацію про навколишній світ людини, про саму людину, про мову. Об'єктивна реальність відбивається індивідуальною свідомістю людини і занурюється в якусь нову гіпотетичну реальність як сукупність суджень. Прості і складні судження формуються за правилами логіки, забезпечують ім істинний характер, тобто відповідність правильного відображення явищ світу. У логіці і семантиці судження вважається теоретично істинним, якщо воно істинне в будь-якому з можливих світів (Kempson, 1995: 32). Моделі судження закріплюються в колективній свідомості. У результаті пізнання світу і себе, через досвід, людина виявляє типові риси і взаємозв'язки окремих 
явищ. Так, наприклад, типовою рисою весни є пробудження природи - танення льоду, струмки, поява листя й інше. Спостерігаючи такі типові явища, людина індуктивно встановлює умовно (причинно)-наслідкову залежність між ними i робить висновок про те, що прийшла весна. У свідомості людини формується і закріплюється модель складного умовно-наслідкового судження, яка відображає умовно-наслідковий взаємозв'язок між елементарними процесами, який об'єктивно існує у природі. Так, обов'язкові елементи єдиного складного судження формуються із простих суджень шляхом об'єднання їх за допомогою імплікації «якщо < ..> то» $(\mathrm{A} \rightarrow \mathrm{B})$.

У реальному світі умова може або передувати наслідку, або відбуватися водночас із ним (Воробйов та ін., 1962: 70). Однак у мисленні - у внутрішньому, духовному, метафізичному, ментальному світі, як і в його мовному відображенні мовленні, людина може переноситися в майбутнє і минуле, конструювати події минулого і майбутнього, тобто події фізично не існують і не існували, але наявні тільки у свідомості людини. Ментальний світ - суб'єктивне відображення реального і гіпотетичного світів $€$ і колективною свідомістю.

Ментальний світ за допомогою мовних знаків і правил відображається у вербальному світі, тобто в мові. Ментальний світ більш пластичний, і в ньому судження, що відображають такі події (процеси), 3 легкістю піддаються ретроспективній трансформації. Інакше кажучи, у своїх думках людина може звернутися як до майбутнього, проєктувати події, ситуації в різних ракурсах, так і до минулого, подумки переживати і заново реконструювати ситуації. На відміну від реального світу, у гіпотетичному світі людина може порушувати послідовність перебігу взаємопов'язаних процесів і відокремлювати їх один від одного. У мові це відображається тим, що: а) наслідкова предикативна одиниця може передувати умовній предикативній одиниці, тобто наслідок може відбуватися раніше умови; б) наслідкова предикативна одиниця й умовна предикативна одиниця можуть функціонувати самостійно. Сама наявність експлікованого в мові одного складного компонента умовно-наслідкового судження передбачає обов'язковість існування іншого компонента єдиної рамкової конструкції.

Така обов'язковість і взаємозалежність компонентів умовно-наслідкового судження уможливлює відносно самостійне функціонування умовної предикативної одиниці і наслідкової предикативної одиниці, оскільки 3 наслідкової предикативної одиниці, що самостійно функціонує, за допомогою ретроспективного аналізу адресатом мовного ланцюжка може виводитися «недостатня» умовна предикативна одиниця; із такої, що самостійно функціонує, умовної предикативної одиниці (на основі знання ситуації) слухачем може виводитися імплікована мовцем наслідкова предикативна одиниця.

Тому імплікація «якщо <...> то», прийнята у формальній логіці для відображення умовнонаслідкового відношення між елементарними процесами реальної об'єктивної дійсності, нездатна, на наш погляд, висловити сутність відносин між двома взаємопов'язаними, елементарними гіпотетичними процесами світу ментальності. «Умовні речення, що суперечать дійсності $<\ldots$..> вимагають чогось більшого, ніж проста імплікація» (Cann, 1994: 230). Це пов'язано з тим, що «природна мова живе палітрою форм, розмаїттям значень, багатством відтінків, і тому іiі не можна вставити в жорсткі рамки математичної логіки» (Приходько, 2000: 190). Адже імплікація умовнонаслідкового судження, що відображає зв'язок процесів об'єктивної дійсності, є «односторонньою», «односпрямованою» $(\mathrm{A} \rightarrow \mathrm{B})$. На рівні думки і в мові, як іiі знаковому, фізичному втіленні, поряд із відношенням А $\rightarrow$ В існує і «зворотне» відношення, коли В передбачає $\mathrm{A}(\mathrm{B} \rightarrow \mathrm{A} /$ $\mathrm{A} \leftarrow \mathrm{B})$, тобто «зворотна» імплікація. Відповідно відношення між частинами нереального умовнонаслідкового періоду $є$ «двосторонньою» імплікацією (А $\leftrightarrow$ В) або еквіваленцією як «з'єднання двох імплікацій» (Allsop, 1992: 41), «кожна 3 яких спрямована у свій бік» (Hurford, 1991: 175). Таке відношення Дж. Хефорд називає "biconditional" (Hurford, 1991: 175), що трактується як «двостороння умовна залежність, рівнозначність». Двостороння імплікація $\mathrm{A} \leftrightarrow \mathrm{B}$ пояснюється тим, що наявність А передбачає існування В, так само, як і наявність В передбачає існування А; або: у мовному ланцюжку фрагмент А усвідомлюється адресатом як вираження нереального наслідку, якщо в даному мовному ланцюжку наявний фрагмент В, усвідомлюваний адресатом як вираження нереального наслідку; і відповідно в мовному ланцюжку фрагмент В усвідомлюється адресатом як вираження нереального наслідку, якщо в даному мовному ланцюжку наявний фрагмент А, усвідомлюваний адресатом як вираження нереальної умови.

Умовне і наслідкове (обумовлене) - понятійні категорії, що вивчаються у філософії, логіці та лінгвістиці, відображають об'єктивні зв'язки, відносини між подіями реальної дійсності. Оскільки зв'язок між умовою і наслідком об'єктивний, він пізнається свідомістю і відображається у складному судженні, мовним вираженням якого $\epsilon$ 
умовно-наслідковий період. У межах складного умовно-наслідкового судження умова і наслідок $\epsilon$ обов'язковими взаємозалежними і такими, що логічно взаємовизначають, складовими частинами. Умовна предикативна одиниця і наслідкова предикативна одиниця в НУНП $є$ обов'язковими взаємозалежними не тільки структурно, але і складовими частинами, що семантично взаємовизначають. Кожна із частин такого судження, тобто експліцитно виражена в реченні предикативна одиниця, співвідноситься в мисленні мовця 3 «подією» або елементарним процесом гіпотетичної дійсності, один із яких сприймається мовцем, і представлена в його мові як умова, що породжує другий процес, що інтерпретується ним як обумовлене (наслідок).

Отже, граматичним значенням повнопредставленого НУНП пропонується вважати співвіднесеність із двома елементарними процесами, представленими в мисленні й мові учасників комунікації як відносно можливими (бажані / небажані) у гіпотетичній дійсності і пов'язаними один 3 одним умовно-наслідковим відношенням, синтаксичний статус якого - взаємозалежність. Умовно-наслідкова залежність між процесами гіпотетичної дійсності встановлюється адресантом у процесі мовлення і впізнається адресатом під час декодування мовного ланцюжка (фрагмент). Це ідеалізована когнітивна модель, інваріант значення всіх НУНП.

Умовно-наслідкові відношення в повнопредставленому НУНП виражаються передусім самою синтаксичною побудовою НУНП, у якому умовна предикативна одиниця і наслідкова предикативна одиниця $\epsilon$ обов'язковими компонентами, що взаємовизначають.

Нижче розглянемо граматичне значення неповнопредставленого НУНП. У мовленні проявляються не тільки наші думки, уявлення, бажання, відношення й емоції, але і те, як усе це організовано в нас у свідомості, тобто ті принципи, за якими «влаштовано» наше колективне бачення світу, те, як ми відокремлюємо головне від другорядного» (Тарасова, 1999: 175). Лінгвісти не можуть безпосередньо проникнути в людський мозок і спостерігати за тим, як там протікають внутрішні процеси. Їм доводиться спостерігати тільки за результатами мозкової діяльності, і тільки аналіз цих результатів (слово, синтагма, речення, текст) «дозволяє висловити припущення щодо «механізмів» процесу вербалізації» (Бацевич, 1997: 30).

Наявність розгалуженої синтаксичної парадигми НУНП зумовлена існуванням двох різновидів мислення: логічного і мовного, які існують в нерозривній єдності, як дві сторони єдиного про- цесу організації думки, який відбувається в одній сфері мовного мислення (Загнітко, 1996: 110). Відповідно до гіпотези Н. Хомського, за незліченною кількістю «поверхневих синтаксичних структур» (різні для різних мов) ховаються «глибинні синтаксичні структури», що відображають загальні схеми вираження думки, кількість яких $є$ порівняно невеликою. Людина, яка опанувала в дитинстві ці «глибинні синтаксичні структури», легко може виводити з них будь-які «поверхневі структури». Такі процеси відбуваються в результаті мовотворчої діяльності з боку адресанта. Процес декодування, розуміння мови йде у зворотному напрямку: адресат, коли сприймає «поверхневі синтаксичні структури», співвідносить їх із засвоєним і закріпленим у свідомості набором «глибинних синтаксичних структур» (Загнітко, 1996: 112).

Оскільки ядром синтаксичної парадигми НУНП $є$ повнопредставленні двокомпонентні нереальні умовно-наслідкові періоди, що складаються з поєднання умовної предикативної одиниці і наслідкової предикативної одиниці, то і їхнє граматичне значення $\epsilon$ інваріантом для структури значення всіх НУНП, «глибинною синтаксичною структурою» для всіх різнооформлених НУНП. Отже, розуміння й експлікація невиражених умови або наслідку відбуваються в результаті взаємодії, співвіднесення на підсвідомому рівні комунікативних моделей 3 ідеальною моделлю. Цим пояснюється і те, що функціонування в мові досить великої різноманітності мовних моделей, змістом яких $є$ вираз обумовленості, не ускладнює ï розуміння для учасників процесу комунікації. Оскільки «форма істотна, сутність формована так чи інакше в залежності від сутності» (Кухаренко, 1974: 427), структурно-композиційні особливості інших різнооформлених НУНП свідчать про наявність особливостей їхнього значення, які виводять такі структури на периферію поля. До таких особливостей належать парцелювання, імплікація, компресія НУНП і регресивне переосмислення контексту, якщо умовно-наслідкова структура представлена в мові в неповному вигляді.

Висновки. Отже, граматичним значенням повнопредставленого НУНП визначено співвіднесеність (через складне умовно-наслідкове судження) із двома елементарними процесами, представленими в мисленні і мовленні учасників комунікації як відносно можливими (не/бажаними) у гіпотетичній дійсності і зв'язаними одне 3 одним умовно-наслідковим відношенням. Таке відношення суб' єктивно встановлюється адресантом у процесі породження мовлення і розпізнається адресатом під час декодування мовленнєвого 
фрагмента. Це ідеалізована когнітивна модель нереального умовно-наслідкового судження, інваріант граматичного значення всіх НУНП. Саме наявність у свідомості людини ідеалізованої когнітивної моделі нереального умовно-наслідкового судження як нерозривної діалектичної єдності умови і наслідку (рівень мислення) у конкретних умовах мовленнєвої ситуації дає можливість комунікантам реалізовувати свої специфічні прагматичні інтенції (рівень мовлення) за допомогою: а) парцеляції НУНП (у разі контактного або дистантного розташування умовної або наслідкової частин); б) компресії НУНП: згортання первинної структури предикації до фрази (слова) або опущення (редукції) прагматично нейтральної, 3 погляду адресанта, частини єдиного цілого.

Граматичним значенням неповно представленого НУНП $є$ співвіднесеність з одним елементар- ним процесом гіпотетичної дійсності, який через імпліцитність ідеалізованої когнітивної моделі нереального умовно-наслідкового судження усвідомлюється як частина єдиного цілого, друга частина якого не експлікована і виявляється адресатом у процесі послідовного сприйняття й інтерпретації мовленнєвого фрагмента. Предикативні одиниці, первісно сприйняті як незалежні прості судження, регресивно переосмислюються як такі частини єдиного нереального умовно-наслідкового судження, що визначають взаємну залежність і обов'язковість наявності одна одної в цій структурі. Отже, вираження умовно-наслідкового відношення між процесами гіпотетичної дійсності є граматичним значенням не стільки форм дієслова, скільки синтаксичної конструкції - НУНП, що служить для мовного вираження складного умовно-наслідкового судження.

\section{СПИСОК ВИКОРИСТАНИХ ДЖЕРЕЛ}

1. Бацевич Ф .С. Когнітивне і вербальне у процесах вербалізації. Мовознавство. Київ : Наукова думка, 1997. № 6. С. 30-36.

2. Воробьев Л. В., Каганов В. М., Фурман А. Е. Основные категории и законы материалистической диалектики. Москва : Изд-во Моск. гос. ун-та, 1962. 360 с.

3. Загнітко А. П. Український синтаксис (науково-теоретичний і навчально-практичний комплекс). Київ : IЗMH, 1996. Ч. 1.202 c. ; Ч. 2. 240 c.

4. Кухаренко В. А. Типы и средства выражения импликации в английской художественной речи. На материале прозы Э. Хемингуэя. Научные доклады высшей школы. Серия «Филологические науки». Москва : Высшая школа, 1974. № 1. C. 72-80.

5. Приходько А. М. Логіко-семантична специфіка сполучників сурядності як складних предикатів першого рангу. Вісник Харківського начіонального університету ім. В. Н. Каразіна. Харків : Константа, 2000. № 500. С. 181-191.

6. Тарасова Е. В. Когнитивные основания системной организации речи. Вісник Харківського державного університету ім. В. Н. Каразіна. Харків : Константа, 1999. № 424. С. 174-183.

7. Allsop L. Student's English Grammar. Heinemann, 1992. 276 p.

8. Cann R. Formal Semantics. Cambridge : Cambridge University Press, 1994. 344 p.

9. Hurford J. R. The evolution of the critical period in language acquisition. Cognition. 1991. № 40. P. 159-201.

10. Kempson Ruth M. Semantic theory. Cambridge : Cambridge University Press, 1995. 216 p.

\section{REFERENCES}

1. Batsevych F. S. Kohnityvne i verbalne v protsesakh verbalizatsii. Movoznavstvo [Cognitive and verbal in the processes of verbalization. Linguistics]. K.: Naukova dumka, 1997. № 6. P. 30-36 [in Ukrainian].

2. Vorob'ev L. V., Kaganov V. M., Furman A. E. Osnovnye kategorii i zakony materialisticheskoj dialektiki [The main categories and regularities of materialist dialectics]. M.: Izdatelstvo Moskovskogo gosudarstvennogo universiteta, 1962.360 p. [in Russian].

3. Zahnitko A. P. Ukrainskyi syntaksys (naukovo-teoretychnyi i navchalno-praktychnyi kompleks) [Ukrainian syntax (scientific-theoretical and educational-practical complex)]. K.: IZMN, 1996. Ch. 1. 202 p.; Ch. 2. 240 p. [in Ukrainian].

4. Kuharenko V. A. Tipy i sredstva vyrazheniya implikacii $v$ anglijskoj hudozhestvennoj rechi. Na materiale prozy E. Hemengueya. Nauchnye doklady vysshej shkoly. Seriya Filologicheskie nauki [Types and means of expressing implications in English artistic speech. Based on E. Hemingway prose. Higher school scientific reports. Series: Philological Sciences]. M.: Vysshaya shkola, 1974. № 1. P. 72-80 [in Russian].

5. Prykhodko A. M. Lohiko-semantychna spetsyfika spoluchnykiv suriadnosti yak skladnykh predykativ pershoho ranhu. Visnyk Kharkivskoho natsional'nogo universytetu im. V. N. Karazina [Logical-semantic specificity of conjunctions as complex predicates of the first rank. Bulletin of the Kharkiv V. N. Karazin National University]. Kharkiv: Konstanta, 2000. № 500. P. 181-191 [in Ukrainian].

6. Tarasova E. V. Kognitivnye osnovaniya sistemnoj organizacii rechi. Visnyk Kharkivskoho derzhavnogo universytetu im. V. N. Karazina [Cognitive bases of systemic organization of speech. Bulletin of the Kharkiv V. N. Karazin State University]. Kharkiv: Konstanta, 1999. № 424. P. 174-183 [in Russian].

7. Allsop L. Student's English Grammar. Heinemann, 1992. 276 p. [in English]

8. Cann R. Formal Semantics. Cambridge: Cambridge University Press, 1994. 344 p. [in English]

9. Hurford J. R. The evolution of the critical period in language acquisition. Cognition. 1991. № 40. P. 159-201. [in English]

10. Kempson Ruth M. Semantic theory. Cambridge: Cambridge University Press, 1995. 216 p. [in English] 